\title{
RANCANG BANGUN TAMAN BERMAIN TRADISIONAL DI PERUMAHAN JOYOGRAND RW 9 KELURAHAN MERJOSARI KOTA MALANG
}

\author{
Suryo Tri Harjanto \\ Dosen Prodi Arsitektur, Fak. Teknik Sipil dan Perencanaan, ITN Malang \\ e-mail: totosuryosaja@gmail.com \\ Hamka \\ Dosen Prodi Arsitektur, Fak. Teknik Sipil dan Perencanaan, ITN Malang \\ e-mail: hamka07@lecturer.itn.ac.id \\ Adhi Widyarthara \\ Dosen Prodi Arsitektur, Fak. Teknik Sipil dan Perencanaan, ITN Malang \\ e-mail: adhiwidyarthara@gmail.com
}

\begin{abstract}
ABSTRAK
Taman bermain tradisional diperumahan Joyogrand masuk dalam kategori Taman Lingkungan Perumahan dan Permukiman berdasarkan Peraturan Menteri Dalam Negeri No. 1 Tahun 2007 mengenai Ruang Terbuka Hijau. Rancang bangun taman bermain tradisional dengan memanfaatkan lahan kosong di lingkungan Perumahan Joyogrand RW 09 Kelurahan Merjosari Kota Malang, bertujuan untuk meminimalisir ketergantungan anak-anak di lingkungan Perumahan Joyogrand terhadap penggunaan gadget yang semakin meningkat di era revolusi industri 4.0 sekarang ini. Rancang bangun taman bermain tradisional ini merupakan upaya untuk menambah ruang terbuka lingkungan yang berfungsi sebagai ruang sosial warga sekitar. Metode yang digunakan dalam kegiatan pengabdian kepada masyarakat ini adalah pendekatan partisipatori sosial dan kualitatif analisis deskriftif, observasi lapangan dan sosial masyarakat, untuk mengidentifikasi keterlibatan warga dalam menentukan konsep taman bermain tradisional yang diinginkan, sebagai pemenuhan terhadap kebutuhan ruang komunal lingkungan perumahan, dan melestarikan nilainilai kearifan lokal yang terdapat pada permainan tradisional. Hasil kegiatan rancang bangun ini menunjukkan bahwa tingkat parsitipasi warga dalam kegiatan ini sangat tinggi dan tingkat pemanfaatan oleh warga (khususnya anak-anak) pasca bangun juga menunjukkan hal yang positif.
\end{abstract}

Kata kunci : Rancang bangun, taman bermain, ruang terbuka

\begin{abstract}
Joyogrand's traditional playgrounds are included in the category of Housing and Settlement Environmental Parks based on Minister of Home Affairs Regulation No. 1 of 2007 concerning Green Open Space. The design of building a traditional playground by utilizing vacant land in the neighborhood of Joyogrand RW 09 Kelurahan Merjosari Malang, aims to minimize the dependence of children in Joyogrand Housing to the increasing use of gadgets in the current industrial revolution 4.0 era. The
\end{abstract}


design of building a traditional playground is an effort to increase the open space of the environment that functions as a social space for the local residents. The methods used in community service activities are social participatory approaches and qualitative descriptive analysis, field observations and community social, to identify the involvement of citizens in determining the desired traditional playground concept, as a fulfillment of the communal space needs of the residential environment, and preserving values the value of local wisdom found in traditional games. The results of the design activities show that the level of community participation in this activity is very high and the level of utilization by residents (especially children) post-build also shows a positive thing.

\section{Keywords : Design and build, playground, open space}

\section{PENDAHULUAN}

Rancang bangun taman bermain tradisional dilingkungan RW. 09 Kelurahan Merjosari, merupakan bentuk komitmen warga RW 09 Perumahan Joyogrand untuk memberdayakan potensi semua kelompok umur, dengan cara merencanakan ruang-ruang komunal sebagai sarana interaksi sosial budaya, berupa taman-taman tematik dengan memanfaat lahan fasilitas umum yang dimiliki warga di lingkungan RW 9 Perumahan Joyogrand. Penelitian menunjukkan bahwa penggunaan gadget memiliki dampak positif, namun juga memiliki dampak negatif yaitu membuat siswa menjadi individual dan mementingkan diri sendiri, serta gadget membuat siswa lebih aktif dimedia sosial dibandingkan belajar jika digunakan secara berlebihan, (Harfiyanto et al, 2015). Menurut (Manumpil et al, 2015) bahwa siswa yang semakin jarang menggunakan gadget memiliki tingkat prestasi yang lebih tinggi. Menurut (Novitasari \& Khotimah, 2016) bahwa perlu adanya pembatasan waktu penggunaan gadget pada anak-anak dan orang tua diharapkan lebih mengenalkan lingkungan sekitar.

Taman bermain tradisional ini berfungsi sebagai sarana pembelajaran khususnya bagi anak-anak, melalui permaian yang bersifat nyata yang diharapkan mampu mengurangi ketergantungan anak-anak terhadap permainan digital pada gadget di era revolusi industri 4.0 yang semakin pesat perkembangannya. Selain itu, taman ini dimaksudkan sebagai ruang terbuka lingkungan warga untuk saling berinteraksi.

Kegiatan ini dilaksanakan dengan melibatkan mitra dan partisipasi warga setempat. Mitra yang bekerja sama dalam program ini adalah Kelompok Karang Taruna Singosongo sebagai Mitra 1 dan Kelompok PKK RW 09 sebagai Mitra 2. Kedua mitra ini merupakan bagian dari kelompokkelompok kegiatan warga RW 9 Kelurahan Merjosari, sehingga kedua mitra ini sudah mengetahui kondisi sosial budaya warga yang berada di lingkungan RW 9. Kedua mitra ini masing-masing memiliki potensi dalam mewujudkan kegiatan rancang bangun ini. Mitra 1 (Karang Taruna) dapat membantu dari segi ide-ide sosial budaya kemasyarakatan dan Mitra 2 (Kelompok PKK RW 9) membantu dari segi sosialisasi dan mobilisasi anak- 
anak khususnya anak-anak yang ada di PAUD BUNGA CEMPAKA dan SD Negeri 5 Merjosari yang berada di lingkungan RW 9.

\section{TINJAUAN PUSTAKA}

\subsection{Rancang bangun}

Perancangan adalah sebuah proses untuk mendefinisikan sesuatu yang akan dikerjakan dengan menggunakan teknik yang bervariasi serta di dalamnya melibatkan deskripsi mengenai arsitektur serta detail komponen dan juga keterbatasan yang akan dialami dalam proses pengerjaanya. pembangunan atau bangun adalah kegiatan menciptakan system, benda, atau objek baru maupun mengganti dan memperbaiki sistem yang telah ada secara keseluruhan, (Pressman, 2009). Perancangan adalah suatu proses kreatif yang merespon suatu kondisi dengan berkonsenterasi pada ide, arti, dan nilai-nilai dengan cara membayangkan dan mencari kemungkinan, yang berasal dari pengalaman. (Lynch dan Hack, 1984). Perancangan arsitektur terdapat langkah atau tahapan kegiatan yang harus dilakukan, agar didapatkan persiapan, proses dan hasil perancangan yang baik.

\subsection{Ruang terbuka hijau}

Ruang terbuka hijau adalah ruang-ruang dalam kota atau wilayah yang lebih luas, baik dalam bentuk area atau kawasan maupun dalam bentuk area memanjang atau jalur. Ruang terbuka hijau dalam kawasan merupakan salah satu infrastruktur hijau kota yang akan membentuk kota itu sendiri yang akan memenuhi kebutuhan masyarakat publik. Secara fisik RTH dapat dibedakan menjadi RTH alami yang berupa habitat liar alami, kawasan lindung dan taman-taman nasional, maupun RTH non-alami atau binaan yang seperti taman, lapangan olah raga, dan kebun bunga. Dari segi fungsi RTH berfungsi secara ekologis, sosial/budaya, arsitektural, dan ekonomi (Hendriani, 2016).

Ruang terbuka hijau merupakan ruang terbuka publik yang direncanakan pada suatu kawasan yang tersusun atas ruang terbuka hijau dan ruang terbuka non hijau. Ruang terbuka hijau memiliki fungsi dan peran khusus pada masing-masing kawasan yang direncanakan dalam bentuk penataan tumbuhan, tanaman dan vegetasi agar dapat berperan dalam mendukung fungsi ekologis, social budaya dan arsitektural sehingga dapat memberi manfaat optimal bagi ekonomi dan kesejahteraan masyarakat (Setiyono dan Sidiq, 2018). Ruang terbuka sebagai ruang publik mempunyai peranan sebagai wadah yang dapat menampung aktivitas tertentu dari masyarakat wilayah tertentu, karena itu ruang terbuka mempunyai kontribusi yang akan diberikan kepada manusia yang berupa dampak positif. Ruang terbuka memiliki fungsi umum sebagai tempat bermain dan berolahraga, tempat bersantai, tempat komunikasi sosial, tempat menunggu ruang peralihan dan fungsi ekologis sebagai penyegar udara, menyerap air hujan, pengendali banjir, memelihara ekosistem tertentu (Sudarwani dan Ekaputra, 2017). 


\subsection{Partisipatori desain}

Pendekatan partisipasi sosial ini dimaksudkan agar masyarakat dapat berperan langsung pada lingkungan mereka, sehingga tumbuh rasa kebersamaan dan rasa memiliki terhadap apa yang telah dikerjakan secara bersama-sama. Partisipasi merupakan pemberdayaan (engagement) dari kelompok sasaran (affected group) dalam satu atau lebih siklus kegiatan: desain, implementasi, monitoring, dan evaluasi dan secara metodologis, bentuk-bentuk partisipasi dalam melakukan observasi meliputi (1) Partisipasi pasif (passive participation) warga tidak terlibat langsung, (2) Partisipasi moderat (moderate participation) warga terlibat dalam beberapa kegiatan, (3) Partisipasi aktif (active participation) warga terlibat dalam sebagian besar kegiatan, dan (4) Partisipasi lengkap (complete participaion): warga terlibat langsung dalam semua kegiatan, (Sugiono, 2009). Partisipatif desain adalah sebuah proses yang secara aktif diikuti oleh seluruh stakeholder pada proses dan prosedur desain, stakeholder yang terlibat adalah warga sekitar lokasi yang akan menjadi future user, (Sanoff 2000).

\section{METODE KEGIATAN}

Metode yang digunakan dalam kegiatan pengabdian masyarakat ini adalah Pendekatan partisipasi sosial yaitu metode pendekatan partisipasi aktif (active participation) yakni warga terlibat dalam sebagian besar kegiatan dan dilakukan untuk memberdayakan potensi warga, bekerjasama dengan tim pengusul dan mitra beserta beberapa mahasiswa dari perguruan tinggi tim pengusul. Hal ini dilakukan untuk tetap menjaga karakter kegotongroyongan warga RW 09 Kel. Merjosari. Pendekatan partisipasi ini dilaksanakan pada saat proses diskusi terkait konsep desain, pengadaan dan pembuatan sarana dan prasarana permainan tradisional (prototype/alat permainan), papan atau buku petunjuk atau tata cara permainan dan kelengkapan-kelengkapan lainnya serta implementasi penggunaan taman bermain tradisional. Pengumpulan data didapatkan dari proses observasi dan diskusi bersama antara pengusul, mitra dan warga, untuk menentukan konsep rancangan taman.

\section{HASIL DAN PEMBAHASAN}

\section{Lokasi objek}

Lokasi objek terletak di RW. 09 Kelurahan Merjosari yang merupakan salah satu wilayah di Kecamatan Lowokwaru Kota Malang yang terletak di bagian Barat Kota Malang dengan jarak tempuh $\pm 5 \mathrm{~km}$ dari pusat kota Malang. Secara geografis terletak pada koordinat 1120 06' - 1120 07' Bujur Timur dan 70 06' - 80 02' Lintang Selatan. RW. 09 Kelurahan Merjosari memiliki batas wilayah sebagai berikut :

- Sebelah Utara : RW. 02 Kelurahan Tlogomas

- Sebelah Timur : RW. 08 Kelurahan Merjosari

- Sebelah Selatan : Lahan kosong

- Sebelah Barat : RW. 11 Kelurahan Merjosari 


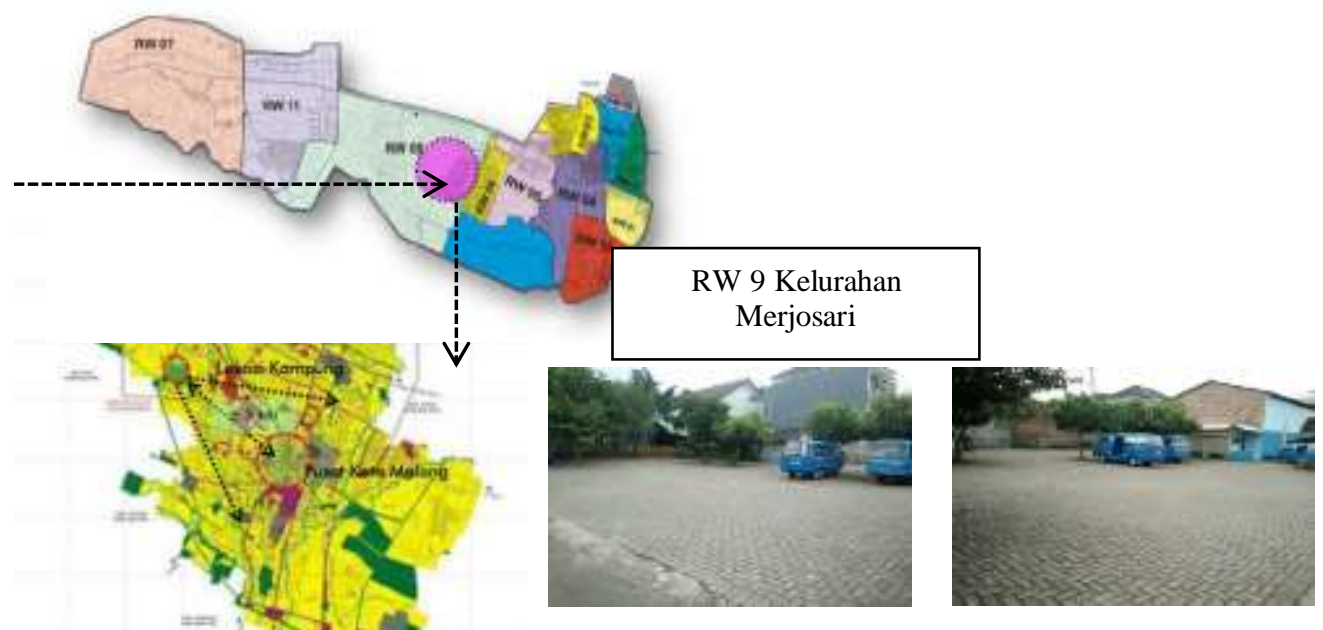

Gambar. 1. Gambaran lokasi objek

(Sumber: Survey lapangan, 2019)

Lokasi taman bermain tradisional ini akan memanfaatkan fasilitas umum berupa ruang terbuka yang berada di RW 9. Berdasarkan kesepakatan bersama antara Ketua RW 9, Tim Pengusul dan Mitra maka taman bermain tradisional ini akan memanfaatkan lahan terminal bayangan angkutan umum (angkot) yang terletak di sebelah gedung serbaguna RW 9. Pemilihan lokasi ini berdasarkan beberapa pertimbangan sebagai beikut:

a. Pusat kegiatan Mitra 1 Karang taruna dan Mitra 2 Kelompok PKK berada di Gedung Serbaguna, sehingga memudahkan dalam hal kepengurusan dan pelaksanaan kegiatan,

b. Letaknya berada didekat fasilitas umum lainnya seperti Masjid AlIkhlas, SDN 5 Merjosari, dan PAUD BUNGA CEMPAKA yang dilaksanakan di gedung serbaguna,

c. Dibandingkan dengan lahan kosong yang lainnya, kondisi fisik terminal bayangan ini sudah dipaving, sehingga mengurangi pembiayaan dari segi fisik dan bisa fokus pada penyediaan sarana dan prasarana permainan tradisional itu sendiri,

d. Jam operasional terminal bayangan ini hanya beroperasi hingga pukul 15:00, sehingga pemanfaatan terminal sebagai taman bermain tradisional dapat digunakan setelah jam tersebut hingga sebelum waktu magrib.

\section{Analisis situasi}

Berdasarkan pada hasil observasi dan diskusi awal bersama mitra dan warga, berikut ini uraian analisis situasi yang menjadi pokok permasalahan dilokasi objek: 
a. Secara umum Mitra 1 Karang Taruna butuh sebuah objek kegiatan yang memiliki unsur tradisi dan budaya lokal yang dapat dilestarikan dan Mitra 2 PKK RW 9 membutuhkan sebuah wadah bagi anak-anak untuk meningkatkan interaksi sosial terhadap lingkungan sekitarnya,

b. Tidak adanya wadah/tempat bermain bagi anak-anak di lingkungan Perumahan Joyogrand RW 9 Kelurahan Merjosari, sehingga anak-anak di lingkungan RW 9 Kelurahan Merjosari ini bermain di jalan-jalan lingkungan perumahan,

c. Warga belum memiliki ide jenis tematik taman bermain dan permainan apa yang akan disediakan di lingkungan RW 9 Kelurahan Merjosari, yang mampu meningkatkan interaksi sosial budaya anak-anak dengan lingkungannya,

d. RW 9 Perumahan Joyogrand memiliki beberapa fasilitas berupa ruang terbuka/lahan kosong yang dapat dimanfaatkan sebagai lokasi tapak taman bermain ini, sehingga perlu penentuan lokasi taman bermain sesuai dengan kriteria taman bermain yang akan di desain dan kemudahan aksesibilitas,

e. Perlu adanya konsep desain taman bermain yang ekonomis, menyenangkan, memiliki nilai sosial budaya, dan keunikan yang nantinya dapat dipromosikan ke masyarakat umum agar dapat menjadi tujuan wisata bagi masyarakat umum.

Berdasarkan pada uraian diatas maka pokok permasalahan utama yang disepakati antara pihak pengusul dengan mitra beserta pengurus RW 9 Perumahan Joyogrand Kelurahan Merjosari adalah menyediakan wadah bermain anak-anak yang berada di lingkungan RW 9 pada khususnya dan juga untuk lingkungan sekitarnya. Taman bermain yang dimaksud adalah taman bermain yang menyediakan sarana dan prasarana permainan yang mengandung nilai-nilai tradisi dan budaya lokal, yang lokasinya memanfaatkan fasilitas umum berupa lahan kosong atau ruang terbuka yang dimiliki oleh warga RW 9. Taman bermain ini bertujuan untuk mengurangi ketergantungan anak-anak terhadap penggunaan gadget yang berlebihan, dalam hal ini anak-anak dilingkungan RW 9 ini diharapkan dapat lebih aktif dalam bersosialisasi dan berinteraksi secara positif terhadap lingkungannya.

\section{Proses diskusi}

Partisipasi warga dalam rancang bangun taman bermain tradisional dilingkungan RW 9 Kelurahan Merjosari merupakan bentuk proses partisipasi aktif (active participation) dalam diskusi dan implementasi, yaitu dalam diskusi mengenai pembagian tugas, ide dan konsep, penentuan lokasi, dan implementasi desain. Kegiatan ini diawali dengan melakukan sosialisasi dan diskusi terkait dengan ide dan masukan awal mengenai konsep rancangan taman bermain tradisional. 

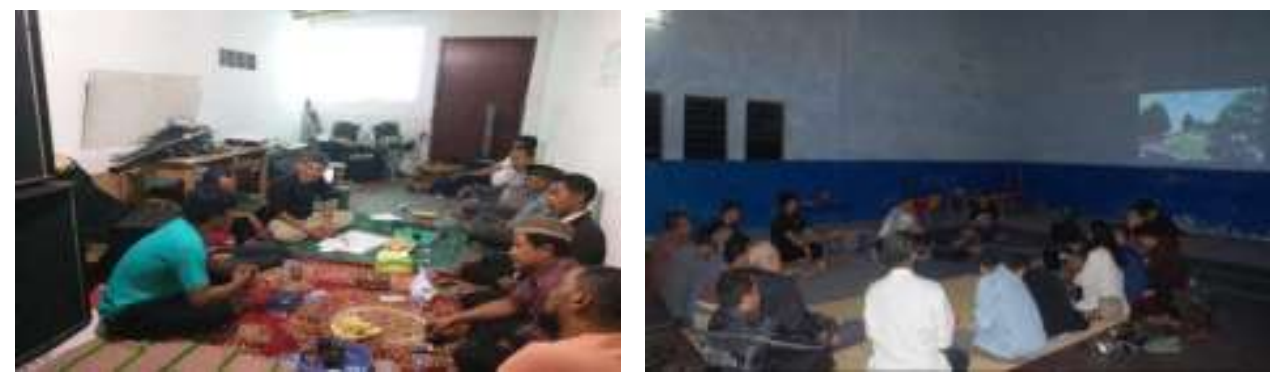

Gambar. 2. Proses sosialisasi dan diskusi kegiatan

(Sumber: Data lapangan, 2019)

Berdasarkan pada hasil diskusi bersama maka dibutuhkan pembagian tugas antara Tim Pengusul, Mitra, dan Warga sebagai berikut Tabel 1.

Tabel 1. Hasil diskusi pembagian tugas

No Anggota Tim Tugas

1. Tim/ anggota Menyusun dan merencanakan kegiatan secara keseluruhan, pengusul berfungsi sebagai koordinator seluruh tim, dan sebagai penerjemah konsep desain taman bermain dalam bentuk visual berdasarkan hasil diskusi bersama mitra dan perwakilan warga, Menyusun rencana kegiatan yang bekerjasama dengan Kedua Mitra, kemudian mensosialisasikan ke warga

2. Mahasiswa Membantu observasi dan survei lapangan, membuat visualisasi konsep desain dan poster/ banner permainan tradisional serta cara bermainnya

3. Mitra 1 Karang Mengumpulkan jenis-jenis permainan yang akan diterapkan beserta Taruna RW 09 aturan dan tata cara permainannya

4. Mitra 2 (PKK Mengumpulkan data jumlah anak-anak dilingkungan RW 09 Kel. RW 9) Merjosari, mendata kegiatan anak-anak dan mensosialisasikan kegiatan pada warga khususnya anak-anak

5. Warga Berpartisipasi dalam mengimplementasikan desain, pembuatan alat permainan tradisional, pengecatan taman dan lapangan serta pengguna taman bermain tradisional

Berikut ini daftar permainan yang telah dikumpulkan oleh mitra Karang Taruna untuk diterapkan pada desain taman bermain, Table 2.

Tabel 2. Tabel jenis permainan

\begin{tabular}{ccc}
\hline No. & Jenis Permainan & Ukuran/Kelengkapan \\
\hline 1. & Engklek & $60 \mathrm{~cm} \times 60 \mathrm{~cm} /$ kotak \\
\hline 2. & Gobak Sodor & $9 \mathrm{~m} \times 6 \mathrm{~m}$ \\
\hline 3. & Lintasan Egrang & $10 \mathrm{~m} \times 3 \mathrm{~m}$ \\
\hline 4. & Lapangan Voli & $18 \mathrm{~m} \times 9 \mathrm{~m}$ \\
\hline 5. & Lapangan Futsal Mini & $18 \mathrm{~m} \times 9 \mathrm{~m}$
\end{tabular}




\begin{tabular}{lcc}
\hline 6. & Egrang Bambu & 3 pasang \\
\hline 7. & Egrang batok & 3 pasang \\
\hline 8. & Bakiak/terompah panjang & 3 pasang ukuran.anak \\
\hline 9. & Lompat Tali/ tali Putar & 2 buah tali \\
\hline 10. & Gasingan & 3 buah gasing bambu \\
\hline 11. & Yoyo & 3 buah yoyo kayu \\
\hline 12. & Dakon / Congklak & 2 buah dakon plastik \\
\hline 13. & Hola Hoop & 3 buah \\
\hline 14. & Pletokan / pistol Bambu & 4 buah \\
\hline 15. & Kretekan baling-baling & 3 buah \\
\hline 16. & Terbang/Genderang & 3 buah \\
\hline 17. & Ular Naga & - \\
\hline 18. & Petak Umpet & - \\
\hline 19. & Bentengan & - \\
\hline 20. & Ular Tangga & 1 unit \\
\hline
\end{tabular}

Lapangan voli dan futsal mini disediakan untuk mengakomodir kelompok umur remaja dan dewasa untuk berolahraga ditaman ini, sehingga taman ini tidak hanya berfungsi untuk permainan tradisional tapi juga untuk sarana olahraga untuk seluruh warga Perumahan Joyogrand RW 9 Kelurahan Merjosari. Berikut ini data jumlah berdasarkan kelompok usia yang, penduduk RW. 09 terbagi dalam komposisi yang dihimpun oleh kelompok PKK RW 9 sebagai berikut, Gambar 5.

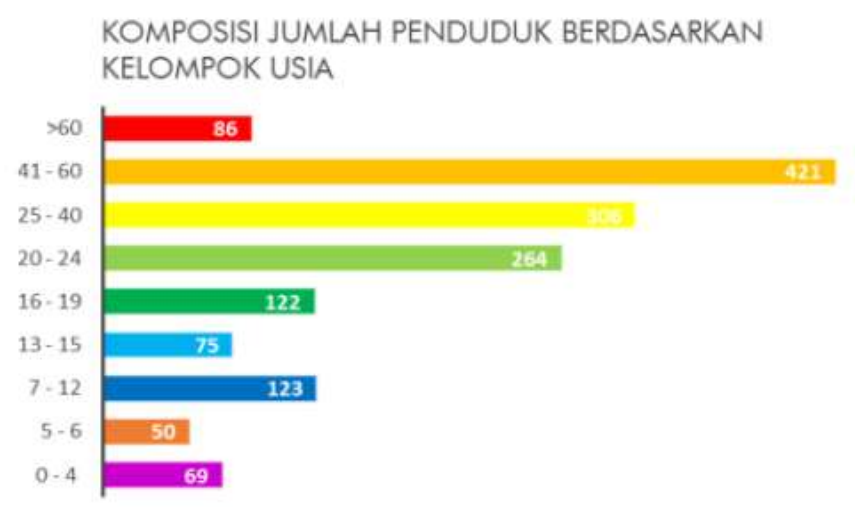

Gambar. 3. Proses sosialisasi dan diskusi kegiatan (Sumber: PKK RW 9, 2019)

Data pada Gambar 5 menunjukkan bahwa kelompok umur warga RW 9 sangat berpotensi menjadikan taman bermain ini menjadi ruang publik yang bermanfaat bagi warga sekitar. Berdasarkan pada jumlah tersebut, maka taman bermain ini tidak hanya diperuntukkan bagi anak-anak saja, tetapi juga untuk remaja atau dewasa, sehingga disediakan garis lapangan voli dan futsal. 


\section{Konsep rancangan}

- Ide rancangan

Ide tematik taman bermain ini diperlukan untuk menjawab permasalahan mengenai sosial budaya yang terkait Mitra 1 Karang Taruna dan permasalahan perkembangan anak-anak yang terkait perioritas dari Kelompok PKK RW 9. Berdasarkan pada hasil diskusi antara tim pengusul dan mitra maka disepakati bahwa tematik taman bermain yang akan diterapkan adalah jenis permainan tradisional.

Permainan tradisional ini dianggap tepat untuk menjawab permasalahan Mitra 1 Karang Taruna yang fokus pada pelestarian tradisi dan budaya lokal. Kenyataan bahwa permainan tradisional saat ini sudah jarang ditemui, khususnya di wilayah perkotaan yang sudah lama tergusur oleh perkembangan permainan modern yang berbasis gadget, sehingga perlu dilakukan tindakan pelestarian terhadap permainan tradisional melalui taman bermain tradisional. Namun, selain permainan tradisional juga disediakan permainan olahraga seperti voli, dan futsal untuk mengakomodir kelompok umur dewasa bapak-bapak atau ibu-ibu.

Konsep desain taman bermain tradisional ini akan banyak menampilkan suasana permainan tradisional, seperti pembuatan garis-garis lapangan untuk jenis permainan tradisional dalam wujud warna-warni yang colourfull, pembuatan mural-mural cerita atau permainan tradisional pada dinding maupun pada permukaan paving.

Menata area jenis-jenis permainan tradisional yang dilengkapi dengan petunjuk atau tata cara permainan. Penyediaan sarana dan prasarana berupa alat-alat permainan tradisional. Untuk merencanakan konsep taman bermain tradisional ini maka perlu diketahui jenis-jenis permainan tradisional yang akan dibuat di taman ini, hal ini perlu pendataan lebih lanjut oleh tim pengusul dan mitra. Maka target luaran yang ingin dicapai adalah sebagai berikut: (a). Berupa konsep dan desain Taman Bermain Tradisional RW 9 Kelurahan Merjosari, (b). Sarana dan prasaran permainan tradisional berupa alat permainan tradisional, lapangan permainan tradisional, dan buku tata cara atau petunjuk permainan, (c). Mural dinding atau lantai yang menggambarkan cerita atau suasana anak-anak bermain permainan tradisional ataupun hal-hal yang terkait dengan permainan tradisional, dan (d). Demo/ujicoba permainan tradisional di Taman Bermain Tradisional RW 9 Kelurahan Merjosari bersama anak-anak dan didampingi oleh orang tua dan warga beserta tim pengusul dan mitra.

Berikut ini gambaran konsep desain taman bermain tradisional yang merupakan hasil diskusi bersama antara mitra dan warga RW 09, Gambar 4. 

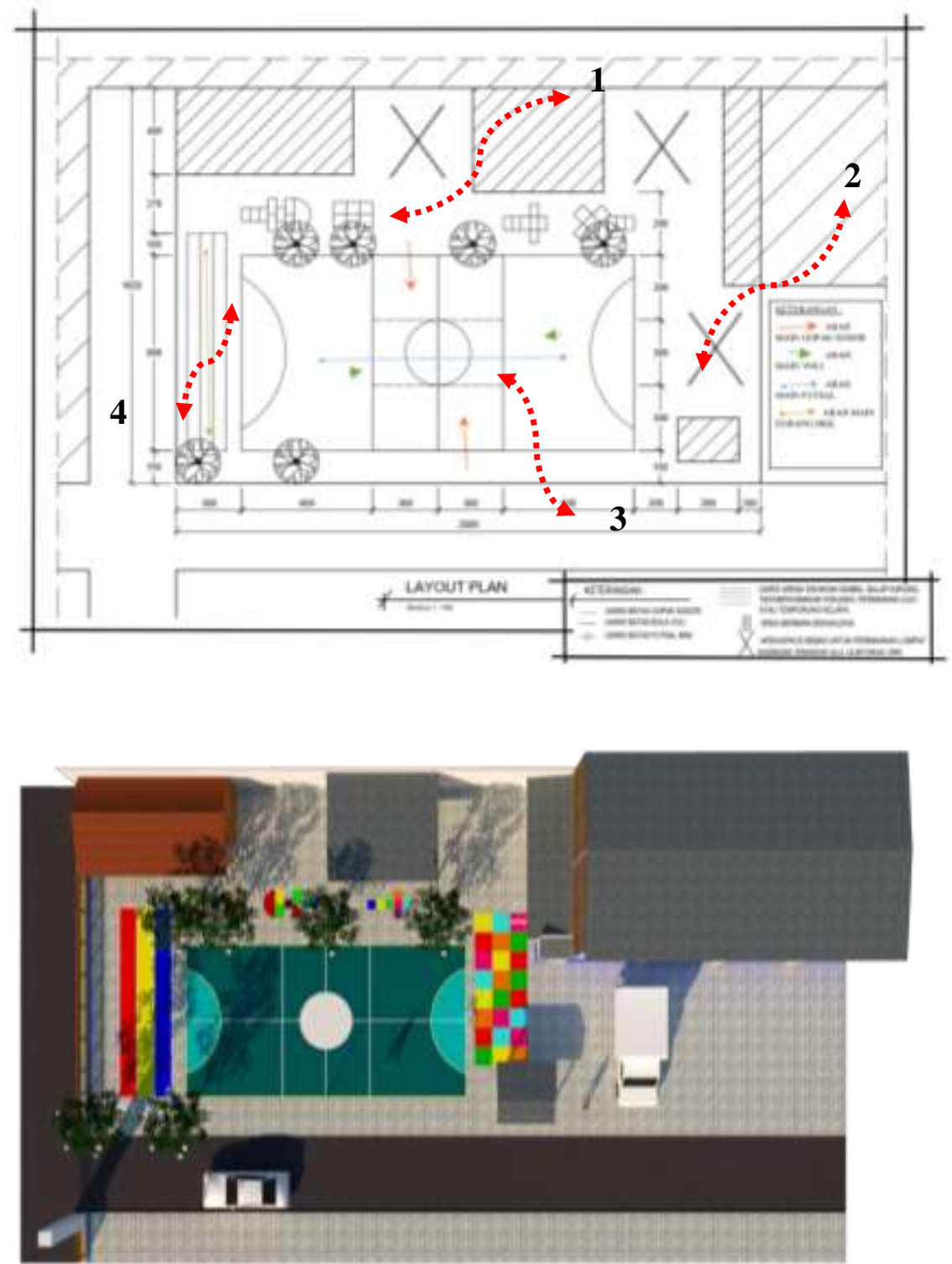

Gambar. 4. Layout plan taman bermana

(Sumber: Mahasiswa Praktek Kerja, 2019) 


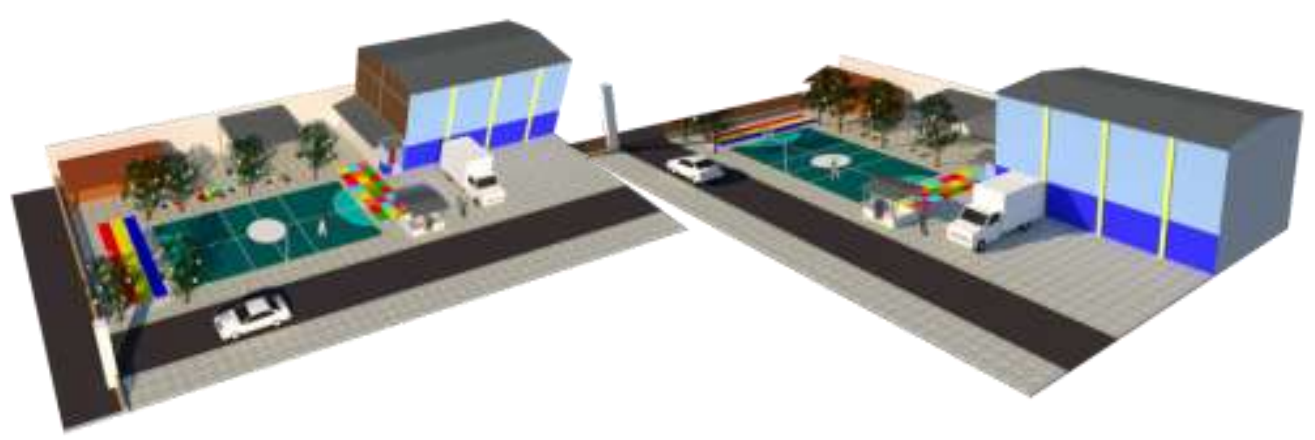

Gambar. 5. Perspektif taman bermain

(Sumber: Mahasiswa Praktek Kerja , 2019)

\section{Partisipasi implementasi desain}

Proses penerapan rancangan pada kegiatan ini adalah dengan melibatkan warga RW 09 secara langsung, yang meliputi 2 tahapan, yaitu tahapan proses pengukuran berdasarkan gambar rancangan, dan tahap proses pengecatan.

a. Tahap pengukuran dan sketsa gambar pada tapak

Tahapan ini meliputi proses sketsa objek permainan di lapangan beserta penempatan pada lapangan sesuai dengan ukuran gambar rancangan, di lanjutkan pembuatan garis as pada tapak dengan menggunakan kapur. Berikut ini gambaran kegiatan proses tahapan yang pertama Gambar 6.
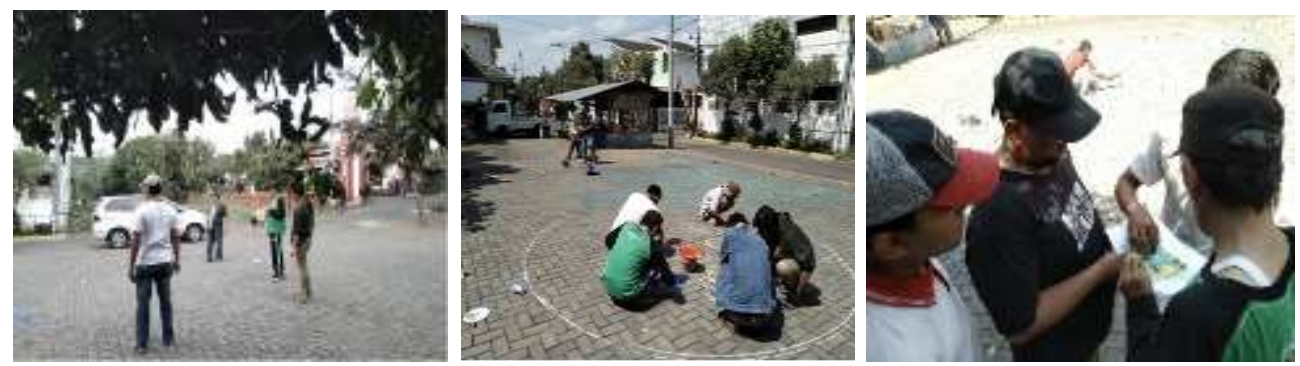

Gambar. 6. Proses penerapan tahap pengukuran

(Sumber: Data lapangan , 2019) 


\section{b. Tahap pengecatan}

Tahapan ini meliputi proses pengecatan lapangan voli, area jalur egrang, engklek dan ular tangga. Pengecatan lapangan voli serta penebalan garis as. Sketsa permainan engklek pada titik yang sudah ada pada gambar rancangan. Pengecatan pada bagian lintasan egrang yang berukuran 10 meter $\mathrm{x} 3$ meter. Proses pengecatan diawali dengan melakukan pembersihan paving terlebih dahulu kemudian dicat sesuai dengan gambar sketsa yang telah dibuat sebelumnya. Berikut ini kegiatan proses pengecatan yang dilakukan oleh warga yang terlibat Gambar 7 .

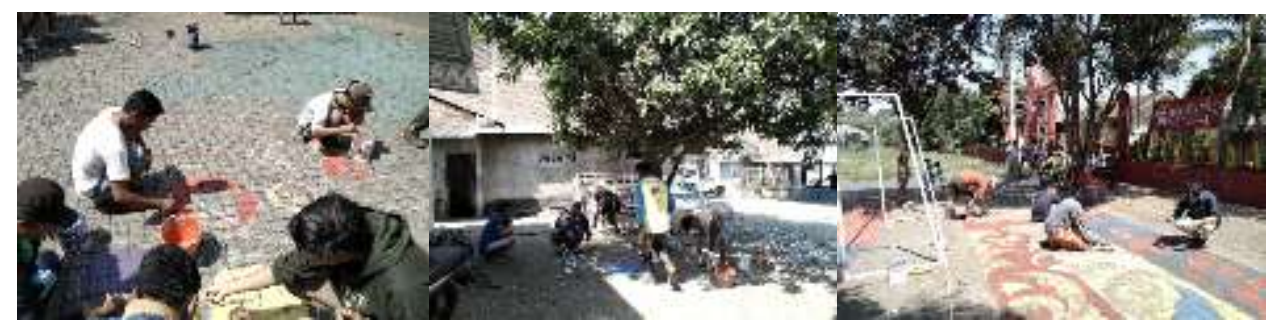

Gambar. 7. Proses pengecatan

(Sumber: Data lapangan, 2019)

\section{Penggunaan Taman Bermain}

Pemanfaatan taman bermain dimanfaatkan warga untuk lomba dan kegiatan 17 Agustus dan kegiatan sehari-hari, khususnya oleh anak-anak kecil yang bermain disore hari seperti main futsal, egrang, dan permainanpermainan lainnya. Berikut ini beberapa susasan kegiatan warga dalam menggunakan taman bermain ini sebagai ruang public/ social Gambar 8.

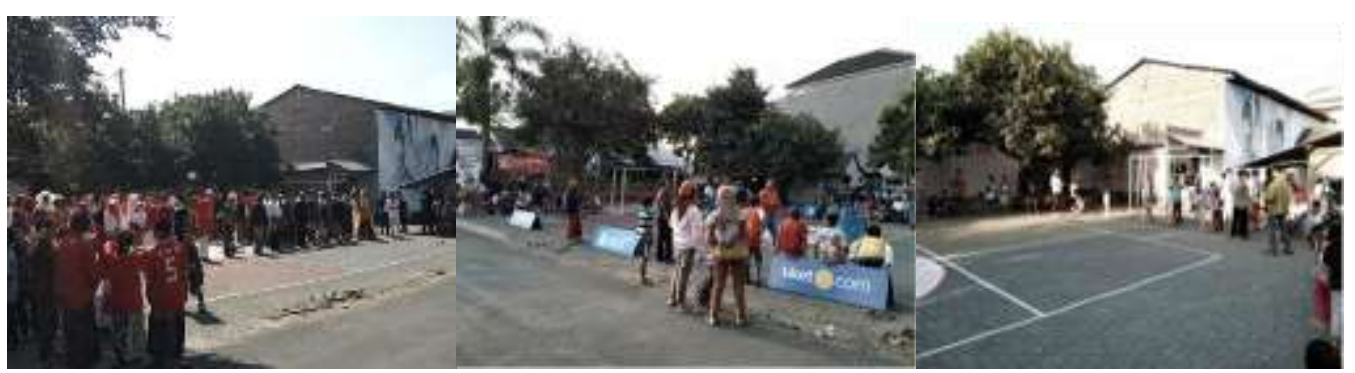

Gambar. 8. Proses pengecatan (Sumber: Data lapangan, 2019)

Permukiman baru memiliki beberapa ruang terbuka sebagai persyaratan yang harus dipenuhi oleh pengembang. Sering kali ruang terbuka tersebut tidak termanfaatkan secara optimal sesuai dengan fungsi 
peruntukannya. Pada satu sisi masyarakat membutuhkan ruang-ruang komunal sebagai tempat untuk berkomunikasi horizontal baik berupa komunikasi dalam bentuk sehari-hari atau dalam bentuk komunikasi berupa mengadakan kegiatan sosial budaya yang rutin maupun isidentil. Dengan adanya wadah berupa ruang-ruang komunal akan mendukung komunikasi social yang pada akhirnya terjadi proses pembelajaran. Dengan melihat partisipasi warga RW 9 yang cukup tinggi dalam kegiatan ini, maka taman bermain tradisional yang diberi nama Taman Dolan Pelangi berhasil menjadi ruang terbuka publik yang secara sosial budaya mampu menjadi ruang interaksi bagi warga yang berkumpul dari berbagai kelompok umur.

Kegiatan pengabdian masyarakat ini menunjukkan bahwa tingkat parsitipatif warga untuk terlibat dalam kegiatan ini tinggi dan tingkat pemanfaatan pasca bangun juga menunjukkan hal yang positif. Dari segi fisik lingkungan, ruang terbuka ini tidak merubah kondisi fisik eksisting sama sekali, dengan tetap mempertahankan vegetasi yang ada, sehingga kondisi lingkungan dapat tetap terjaga. Dari aspek fisik arsitektural perlu adanya peningkatan kualitas secara visual, begitupun dari segi ekonomi perlu direncanakan kegiatan yang saling terhubung dengan taman ini agar dapat menggerakkan ekonomi warga sekitar. Masyarakat butuh masukan khususnya peraturan yang menyangkut dengan penggunaan lahan serta peraturan yang terkait dengan penataan

\section{KESIMPULAN}

Kegiatan pengabdian masyarakat dilingkungan Perumahan Joyogrand RW 9 Kelurahan Merjosari Kota Malang, secara umum mampu melibatkan partisipasi warga yang tinggi mulai dari perencanaan hingga implementasi desain. Manfaat yang paling terasa adalah taman bermain tradisional ini mampu menjadi ruang publik yang menghidupkan kondisi sosial budaya warga dalam berinteraksi. Kondisi fisik eksisting lingkungan tetap dijaga tanpa merubah apapun, sehingga kualitas lingkungan tetap terjaga dan masih dapat ditingkatkan. Khusus untuk aspek fisik arsitektural dan ekonomi perlu perencanaan dan peningkatan lebih lanjut agar taman bermain tradisional ini dapat berfungsi sebagai ruang terbuka lingkungan perumahan permukiman yang menjadi bagian infrastruktur hijau perkotaan.

\section{DAFTAR PUSTAKA}

Harfiayanto, Utomo, \& Budi, 2015. Pola Interaksi Sosial Siswa Pengguna Gadget Di SMA Negeri 1 Semarang. Journal of Educational Social Studies. Universitas Negeri Semarang

Hendriani, 2016. Ruang Terbuka Hijau Sebagai Infrastruktur Hijau Kota Pada Ruang Publik Kota (Studi Kasus : Alun-Alun Wonosobo). Jurnal PPKM II hal. 74-81 
Lynch, Kevin., Hack, Gery. 1984. Site Planning. Massachusetts:Maple-Veil Inc.

Manumpil, Ismanto, \& Unibala, 2015. Hubungan Penggunaan Gadget Dengan Tingkat Prestasi Siswa Di Sma Negeri 9 Manado. Ejoural Keperawatan (e-Kep) Volume 3. Nomor 2.

Novitasari \& Khotimah, 2016. Dampak Penggunaan Gadget Terhadap Interksi Sosial Anak Usia 5-6 Tahun. Jurnal PAUD Teratai. Volume 05 Nomor 03 Tahun 2016, 182-186

Pressman, R., \& Maxim, B. (2009). Software Engineering A Practitioner's Approach (8th ed.). New York McGraw-Hill Higher Education.

Sanoff, Henry. 2000. Community Participation Methods in Design and Planning. USA:John Wiley \& Sons, Inc.

Sudarwani dan Ekaputra, 2017. Kajian Penambahan Ruang Terbuka Hijau di Kota Semarang. Jurnal Teknik Sipil \& Perencanaan 19 (1) Hal. 47 56

Sugiyono (2009). Metode Penelitian Kuantitatif, Kualitatif dan $R \& D$. Penerbit Algabeta Bandung

Setiyono dan Sidiq, 2018. Konsep Infrastruktur Hijau Pada Area Khatulistiwa Park Kota Pontianak. JU-Ke, Volume 2, Nomor 2, hlm. 159 - 164 